\title{
Neurological manifestations in coronavirus disease 2019
}

\section{Teresita Corona, ${ }^{1,2}$ Mayela Rodríguez-Violante2,3 and Guillermo Delgado-García ${ }^{2,3 *}$}

${ }^{1}$ Academia Nacional de Medicina; 'Program for Master's Degree and Doctorate in Medical, Dentistry and Health Sciences, Universidad Nacional Autónoma de México; ${ }^{3}$ Neurodegenerative Diseases Clinical Laboratory, Instituto Nacional de Neurología y Neurocirugía "Manuel Velasco Suárez", Mexico City, Mexico

\begin{abstract}
Coronavirus disease 2019 (COVID-19), an infection caused by severe acute respiratory syndrome coronavirus 2 (SARS-CoV-2), is currently hitting the world in the form of a pandemic. Given that some reports suggest that this infection can also occur with neurologic manifestations, this narrative review addresses the basic and clinical aspects concerning the nervous system involvement associated with this disease. More than one third of patients hospitalized for COVID-19 can present with both central and peripheral neurological manifestations. The former includes dizziness and headache, while the latter includes taste and smell disturbances. Other reported neurological manifestations are cerebrovascular disease and epileptic seizures. According to published reports, neurological disorders are not uncommon in COVID-19 and can sometimes represent the first manifestation of the disease; therefore, neurologists should consider this diagnostic possibility in their daily practice. Since maybe not all COVID-19 neurological manifestations are due to SARS-CoV-2 direct effects, it is important to monitor the rest of the clinical parameters such as, for example, oxygen saturation. Similarly, follow-up of patients is advisable, since whether neurological complications may develop lately is thus far unknown.
\end{abstract}

KEY WORDS: COVID-19. Coronavirus. Neurology. Neurological manifestations. Diseases of the nervous system.

\section{Manifestaciones neurológicas en la enfermedad del coronavirus 2019}

\section{Resumen}

La enfermedad del coronavirus 2019 (COVID-19), infección causada por el coronavirus 2 del síndrome respiratorio agudo grave (SARS-CoV-2), actualmente afecta al mundo en forma de una pandemia. Debido a que algunos reportes apuntan a que esta infección puede cursar también con manifestaciones neurológicas, en esta revisión narrativa se abordan los aspectos básicos y clínicos concernientes a la afectación del sistema nervioso por esta enfermedad. Más de un tercio de los pacientes hospitalizados por COVID-19 pueden presentar manifestaciones neurológicas, tanto centrales como periféricas. Entre las primeras se encuentran el mareo y la cefalea; y entre las segundas, las alteraciones del gusto y el olfato. Otras manifestaciones neurológicas reportadas son la enfermedad vascular cerebral y las crisis epilépticas. Según los informes publicados, los padecimientos neurológicos no son infrecuentes en COVID-19 y en ocasiones pueden representar la primera manifestación de la enfermedad, de modo que los neurólogos deberán considerar esta posibilidad diagnóstica en su práctica cotidiana. Dado que no todas las manifestaciones neurológicas de COVID-19 pudieran deberse a efectos directos de SARS-CoV-2, es importante monitorear el resto de los parámetros clínicos, por ejemplo, la oxigenación. De igual forma, es recomendable el seguimiento de los pacientes, ya que hasta el momento se ignora si las complicaciones neurológicas pueden desarrollarse tardíamente.

PALABRAS CLAVE: COVID-19. Coronavirus. Neurología. Manifestaciones neurológicas. Enfermedades del sistema nervioso.

Correspondence:

*Teresa Corona-Vázquez

E-mail: coronav@unam.mx
Gac Med Mex. 2020;156:313-316

Contents available at PubMed

www.gacetamedicademexico.com

0016-3813/С 2020 Academia Nacional de Medicina de México, A.C.. Published by Permanyer. This is an open access article under the CC BY-NC-ND license (http://creativecommons.org/licenses/by-nc-nd/4.0/). 


\section{Introduction}

Coronavirus disease 2019 (COVID-19) is caused by severe acute respiratory syndrome coronavirus 2 (SARS-CoV-2), an enveloped, positive-sense single-stranded ribonucleic acid virus. In late December 2019, an outbreak of pneumonia of unknown cause occurred in Wuhan, China, and subsequently spread rapidly in that country. Soon after, a new coronavirus was determined to be the causative agent. ${ }^{1,2}$ By April 13,2020 , the outbreak had become a pandemic that affected 213 countries, areas, or territories worldwide, with more than 1.8 million confirmed cases, among which 117,217 (6.3 \%) had a fatal outcome. ${ }^{3}$ In Mexico, 5014 cases and $332(6.6 \%)$ deaths from this disease had been confirmed. The state with the highest number of positive cases and deaths until the moment of this report was and is Mexico City. ${ }^{4}$

SARS-CoV-2 is transmitted mainly through respiratory droplets (of between 5 and $10 \mu \mathrm{m}$ ) and by contact. This coronavirus has also been detected in feces and tears; its incubation period is five days on average, with a range of one to 14 days. Practically all patients (95\%) have symptoms within the first 12.5 days after contact. However, there are asymptomatic carriers who are a potential source of infection. Most common symptoms are fever, fatigue and non-productive cough, followed by headache, nasal congestion, odynophagia, myalgia and arthralgia., ${ }^{1,2}$ However, since late February, the first reports of COVID-19 patients with neurological manifestations appeared. ${ }^{5,6}$ Those initial reports were followed by others that seem to point in the same direction. ${ }^{7}$ Due to the above, this review addresses the basic and clinical aspects concerning nervous system involvement in this disease.

\section{Basic aspects}

Coronaviruses are not completely unknown in neurology; they have been used, for example, in the development of murine models of demyelinating diseases. ${ }^{8}$ There is evidence that identifies neurotropism as a characteristic of coronaviruses. ${ }^{9}$ SARSCoV-2 belongs to the betacoronavirus genus (together with SARS-CoV and MERS-CoV, among others) and the propensity of beta-coronaviruses to neuroinvasiveness is currently known. ${ }^{9}$

The first proposals about SARS-CoV-2 potential neuroinvasiveness were inferred by analogy, considering the evidence obtained from other beta-coronaviruses, especially SARS-CoV, since both share sequences $(79.5 \%)$ and, in addition, use the same receptor to enter human cells, a transmembrane protein called angiotensin-converting enzyme 2 (ACE2), ${ }^{9,10}$ which is normally expressed in the endothelium of cerebral vasculature. ${ }^{11,12}$ Cathepsin L, a lysosomal endopeptidase that is widely distributed in the central nervous system is the mediator in the initial interaction between the virus and the host cell. ${ }^{12}$

Another relevant aspect is the pathophysiology underlying olfactory dysfunction in patients with COVID-19, which apparently is not exclusive to SARSCoV-2 and can be found in infections with other coronaviruses, which are detected in the nasal discharge of patients with olfactory dysfunction. Some of these patients did not recover olfaction after recovering from the infection, even though acoustic rhinometry results were normal, which could indicate that nasal inflammation and associated obstruction are not the only underlying factors for olfactory dysfunction in these infections. ${ }^{13}$ SARS-CoV-2 direct dissemination through retrograde (olfactory or vagal) neuronal transport or systemic circulation has been suggested; ${ }^{11,12}$ the first of both these hypotheses has already been demonstrated in other coronaviruses using murine models. ${ }^{14}$ In one of these models, after passing through the olfactory bulb, SARS-CoV spread to areas anatomically related to the olfactory pathway, including the piriform cortex.13

\section{Clinical aspects}

More than one third (36.4\%) of patients hospitalized for COVID-19 can present with neurological manifestations, both central and peripheral. The former include dizziness and headache, and the latter, changes in taste and smell. Neurological manifestations are more common in patients with severe pneumonia, including cerebral infarction and hemorrhage. In this context, focal seizures can also occur; ;,6 some reports suggest that seizures during this infection may have a higher frequency than that reported in the literature..$^{15}$ Except for cerebrovascular disease (CVD) and waking state alteration, most neurological disorders usually occur early in the course of the disease, i.e., one or two days after the onset of symptoms, or they can even be the first manifestations. ${ }^{5,6}$

Smell and taste alterations occur in most patients with mild to moderate COVID-19 (85.6\% and $88.8 \%$, respectively); in one out of 10 patients, olfactory dysfunction precedes the rest of symptoms. These 
disorders have been reported more frequently in female patients. The most common specific dysfunctions are anosmia (79.6\%) and hypogeusia (78.9\%). Apparently, olfactory dysfunction in the context of COVID-19 is not entirely explained by nasal obstruction or rhinorrhea, as observed in SARS-CoV. In just below one quarter of patients, gustatory dysfunction has been reported as fluctuating. Less than half (44\%) of patients with mild to moderate COVID-19 recover olfaction in the early period. On the other hand, residual gustatory dysfunction has also been observed, although less frequently than olfactory dysfunction. ${ }^{13}$

In the CVD spectrum, infarction is the most common presentation in patients with COVID-19; other manifestations include hemorrhage and venous thrombosis. ${ }^{7}$ Some authors maintain that cerebral hemorrhage in patients with COVID-19 is more common than it has been reported in the literature. ${ }^{16}$ In general, age (71.6 \pm 15.7 years), disease severity and cardiovascular risk are higher in patients with COVID-19 and CVD. The most common cardiovascular risk factors in these patients are hypertension, diabetes mellitus, and a history of CVD. A preliminary report indicated $38 \%$ of mortality in these patients. ${ }^{7}$

One article indicated that SARS-CoV-2 potential neuroinvasiveness could be associated with the respiratory failure that can be caused by COVID-19; in that same document, the findings in one of the survivors ${ }^{9}$ could be interpreted as Ondine syndrome, i.e., respiratory automatism failure during wakefulness.

Other less frequent manifestations are ataxia, ${ }^{5,6} \mathrm{my}-$ elitis ${ }^{17}$ and acute inflammatory demyelinating polyneuropathy. ${ }^{18}$ In Beijing, early in May 2020, the presence of SARS-CoV-2 in the CSF was reported for the first time in a 56-year-old man with symptoms consistent with encephalitis. ${ }^{10,14}$ In a case of meningoencephalitis reported in Japan, SARS-CoV-2 was detected in the CSF, but not in the nasopharyngeal sample. ${ }^{19}$ One case of COVID-19 associated with acute hemorrhagic necrotizing encephalopathy was reported in Detroit, although determining the presence of SARS-CoV-2 in CSF was not possible. ${ }^{20}$

Patients with neurological manifestations of central origin often also present with lymphopenia, thrombocytopenia and azoemia. ${ }^{5,6}$ It is important to consider that possibly not all SARS-CoV-2 effects on the nervous system are direct and could be mediated by hypoxia or the immune response..$^{10,15}$

Although various publications have suggested that patients who died from severe COVID-19 had cerebral edema and partial neuronal degeneration, brain tissue ${ }^{21}$ was not included in the histopathological analysis of tissues obtained during the autopsy..$^{10}$ Subsequent reports did not include this tissue either. ${ }^{22}$ Due to the above, a standardized neuropathological study has recently been proposed in patients with COVID-19. ${ }^{23}$

\section{Therapeutic possibilities}

Some authors have suggested that COVID-19 should be early treated in order to reduce extrapulmonary complications, including neurological involvement; ${ }^{24}$ however, this recommendation is not based on solid evidence. A consensus on the prevention and management of COVID-19 specifically targeted at neurologists was published in Stroke and Vascular Neurology. Among the multiple recommendations, treating patients with mild infection with umifenovir or chloroquine (500 mg every 12 hours for 10 days) for the first few days is suggested. ${ }^{25}$ Recently, it has been discussed that the use of chloroquine in China is associated with a multicenter clinical trial ${ }^{26}$ whose results are not available for consultation. ${ }^{27}$ Currently, multiple clinical trials in China and other countries are recruiting patients to assess the effect and safety of chloroquine in COVID-19. ${ }^{26-28}$ It should be borne in mind that chloroquine can be associated with multiple adverse effects, including QT segment prolongation and ventricular arrhythmias. ${ }^{28}$ On the other hand, umifenovir is not available in Mexico.

Currently, intravenous thrombolysis or mechanical thrombectomy have not been reported in patients with COVID-19 who have been treated with antiplatelet agents (acetylsalicylic acid or clopidogrel) or anticoagulants (low molecular weight heparin) when they have CVD. ${ }^{\text {? }}$

\section{Conclusions}

Neurological conditions are not uncommon in COVID-19 and can sometimes represent the first manifestation of the disease; therefore, neurologists should consider this diagnostic possibility in their routine practice. Given that probably not all neurological manifestations of COVID-19 patients are due to SARS-CoV-2 direct effects, it is important to monitor the rest of patient clinical variables, for example, oxygenation.

\section{Acknowledgements}

Guillermo Delgado García thanks the Consejo Nacional de Ciencia y Tecnología for the national scholarship to pursue a master's degree. 


\section{Conflict of interests}

The authors declare that they have no conflicts of interest.

\section{Funding}

The authors did not receive any sponsoring to carry out this article.

\section{Ethical disclosure}

Protection of people and animals The authors declare that no experiments were performed on humans or animals for this research.

Confidentiality of data The authors declare that no patient data appear in this article.

Right to privacy and informed consent The authors declare that no patient data appear in this article.

\section{References}

1. Zhou M, Zhang X, Qu J. Coronavirus disease 2019 (COVID-19): A clinical update. Front Med. 2020;14:126-135.

2. He F, Deng Y, Li W. Coronavirus disease 2019: What we know? J Med Virol. 2020 Mar 24. DOI: 10.1002/jmv.25766

3. World Health Organization [Internet]. Switzerland: Coronavirus disease (COVID-19) pandemic; 2020. Available at: https://www.who.int/emergencies/diseases/novel-coronavirus-2019

4. Secretaría de Salud [Internet]. México: Comunicado técnico diario nuevo coronavirus en el mundo (COVID-19), 13/04/2020; 2020. Available at: https://beta.slp.gob.mx/SSALUD/Documentos\%20compartidos/Coronavirus/abril/Comunicado Tecnico Diario_COVID-19 2020.04.13.pdf

5. Mao L, Wang M, Chen S, He Q, Chang J, Hong C, et al. Neurologica manifestations of hospitalized patients with COVID-19 in Wuhan, China: A retrospective case series study. medRxiv. 2020 Feb 25. DOI: $10.1101 / 2020.02 .22 .20026500$

6. Mao L, Jin H, Wang M, Hu Y, Chen S, He Q, et al. Neurologic manifestations of hospitalized patients with coronavirus disease 2019 in Wuhan China. JAMA Neurol. 2020:e201127.

7. Li Y, Wang M, Zhou Y, Chang J, Xian Y, Mao L, et al. Acute cerebrovascular disease following COVID-19: A single center, retrospective, observational study. SSRN. 2020 Jan. DOI: 10.2139/ssrn.3550025

8. Libbey JE, Lane TE, Fujinami RS. Axonal pathology and demyelination in viral models of multiple sclerosis. Discov Med. 2014;18:79-89.

9. Li YC, Bai WZ, Hashikawa T. The neuroinvasive potential of SARS-CoV2 may play a role in the respiratory failure of COVID-19 patients $\mathrm{J}$ Med Virol. 2020 Mar 11. DOI: 10.1002/jmv.25728
10. Wu Y, Xu X, Chen Z, Duan J, Hashimoto K, Yang L, et al. Nervous system involvement after infection with COVID-19 and other coronaviruses. Brain Behav Immun. 2020 Jul;87:18-22. DOI: 10.1016/j. bbi.2020.03.031.

11. Baig AM, Khaleeg A, Ali U, Syeda H. Evidence of the COVID-19 virus targeting the CNS: Tissue distribution, host-virus interaction, and proposed neurotropic mechanisms. ACS Chem Neurosci. 2020;11:995-998.

12. Toljan K. Letter to the editor regarding the viewpoint "Evidence of the COVID-19 virus targeting the CNS: tissue distribution, host-virus interaction, and proposed neurotropic mechanism". ACS Chem Neurosci. 2020;11:1191-1194.

13. Lechien JR, Chiesa-Estomba CM, de Siati DR, Horoi M, le Bon SD, Rodríguez $A$, et al. Olfactory and gustatory dysfunctions as a clinical presentation of mild-to-moderate forms of the coronavirus disease (COVID-19): A multicenter European study. Eur Arch Otorhinolaryngol. 2020:1-11.

14. Nath A. Neurologic complications of coronavirus infections. Neurology. 2020;94:809-810. DOI: 10.1212/WNL.0000000000009455.

15. Baig AM. Neurological manifestations in COVID-19 caused by SARSCoV-2. CNS Neurosci Ther. 2020;26:499-501.

16. Wang HY, Li XL, Yan ZR, Sun XP, Han J, Zhang BW. Potential neurological symptoms of COVID-19. Ther Adv Neurol Disord. 2020 Mar 28. DOI: 10.1177/1756286420917830

17. Zhao K, Huang J, Dai D, Feng Y, Liu L, Nie S. Acute myelitis after SARSCoV-2 infection: A case report. medRxiv. 2020 Apr 09. DOI: 10.1101/2020.03.16.20035105

18. Zhao H, Shen D, Zhou H, Liu J, Chen S. Guillain-Barré syndrome associated with SARS-CoV-2 infection: causality or coincidence? Lancet Neurol. 2020;19:383-384.

19. Moriguchi T, Harii N, Goto J, Harada D, Sugawara H, Takamino J, et al. A first case of meningitis/encephalitis associated with SARS-coronavirus-2. Int J Infect Dis. 2020;94:55-58.

20. Poyiadji N, Shahin G, Noujaim D, Stone M, Patel S, Griffith B. COVID-19-associated acute hemorrhagic necrotizing encephalopathy: CT and MRI features. Radiology. 2020 Mar 31;201187. doi: 10.1148/radiol.2020201187.

21. Xu Z, Shi L, Wang Y, Zhang J, Huang L, Zhang C, et al. Pathological findings of COVID-19 associated with acute respiratory distress syndrome. Lancet Respir Med. 2020;8:420-422.

22. Tian S, Xiong Y, Liu H, Niu L, Guo J, Liao M, et al. Pathological study of the 2019 novel coronavirus disease (COVID-19) through post-mortem core biopsies. Mod Pathol. 2020;33:1007-1014. DOI: 10.1038/s41379020-0536-x

23. Cevik L, Alves M, Otero J. Neuropathologists play a key role in establishing the extent of COVID-19 in human patients. Free Neuropathology. 2020;1.11 Apr 02. DOI: 10.17879/freeneuropathology-2020-2736

24. Li Z, Huang Y, Guo X. The brain, another potential target organ, needs early protection from SARS-CoV-2 neuroinvasion. Sci China Life Sci. 2020 Mar 31:1-3. DOI: 10.1007/s11427-020-1690-y

25. Jin H, Hong C, Chen S, Zhou Y, Wang Y, Mao L, et al. Consensus for prevention and management of coronavirus disease 2019 (COVID-19) for neurologists. Stroke Vasc Neurol. 2020 Apr 1. DOI: 10.1136/svn2020-000382

26. Gao J, Tian Z, Yang X. Breakthrough: Chloroquine phosphate has shown apparent efficacy in treatment of COVID-19 associated pneumonia in clinical studies. Biosci Trends. 2020;14:72-73.

27. Cortegiani A, Ingoglia G, Ippolito M, Giarratano A, Einav S. A systematic review on the efficacy and safety of chloroquine for the treatment of COVID-19. J Crit Care. 2020;57:279-283.

28. Yazdany J, Kim AHJ. Use of hydroxychloroquine and chloroquine during the COVID-19 pandemic: What every clinician should know. Ann Intern Med. 2020;172:754-755. 